\title{
Manfaat gerakan salat untuk meningkatkan fleksibilitas punggung bawah pada pengrajin kain blongsong di Kota Palembang
}

\author{
Indri Seta Septadina*, Rulan Adnindya, Wardiansyah, Tri Suciati \\ Bagian Anatomi, Fakultas Kedokteran, Universitas Sriwijaya, Palembang, Indonesia \\ E-mail: Indri.andriansyah@gmail.com
}

\begin{abstract}
Abstrak
Salat merupakan ibadah yang dilakukan umat Muslim minimal lima kali dalam sehari semalam. Salat adalah satu set gerakan fisik sambil membaca ayat al-Quran yang disesuaikan dengan setiap posisi dan gerakan dalam salat. Gerakan salat meregangkan sejumlah otot dan saraf, yang memberikan terapi fisik konstan terhadap semua sendi di tubuh sehingga dapat mencegah terjadinya artritis dan nyeri punggung. Pada kegiatan pengabdian masyarakat ini dilakukan penilaian fleksibilitas punggung bawah pada pengrajin kain blongsong di Kelurahan Tuan Kentang Kecamatan Seberang Ulu 1 Kota Palembang dan edukasi mengenai manfaat gerakan salat sebagai upaya perawatan fleksibilitas punggung bawah. Fleksibilitas punggung bawah pada kelompok laki-laki bernilai sangat baik $(36,4 \%)$, baik $(36,4 \%)$, dan cukup $(27,2 \%)$. Sementara pada kelompok perempuan, nilai fleksibilitasnya juga sangat baik $(47,4 \%)$, baik $(15,8 \%)$, dan cukup $(36,8 \%)$. Tidak ada satupun peserta yang memiliki gangguan pada fleksibilitas punggung bawah.
\end{abstract}

Kata kunci : Salat, Fleksibilitas, Punggung Bawah

\begin{abstract}
The benefits of prayer movements to increase lower back flexibility on the craftsman of the cloth at Palembang. Prayer is a worship performed by Muslims at least five times a day and night. Prayer is a set of physical movements while reciting verses of the Koran that are adapted to each position and movement in prayer. Prayer movements stretch a number of muscles and nerves, which provide constant physical therapy to all joints in the body so as to prevent arthritis and back pain. In this activity an assessment of lower back flexibility was carried out on the craftsman of the cloth in the village of Tuan Kentang in the District of Seberang Ulu 1 in the city of Palembang and education on the benefits of the prayer movement as an effort to care for lower back flexibility. Lower back flexibility in the group of men is very good (36.4\%), good (36.4\%), and sufficient (27.2\%). While in the group of women, the value of flexibility is also very good (47.4\%), good (15.8\%), and sufficient (36.8\%). None of the participants had impaired lower back flexibility.
\end{abstract}

Keywords: Pray, Flexibility, Low Back 


\section{PENDAHULUAN}

Fleksibilitas tubuh manusia mengalami perkembangan yang signifikan pada masa anakanak dan mencapai puncaknya saat masa remaja. Latihan fleksibilitas pada masa ini dapat mencegah terjadinya penurunan fleksibilitas dengan cara melakukan beberapa latihan fisik. ${ }^{1}$ Salah satu latihan yang berhubungan dengan peningkatan fleksibilitas, terutama fleksibilitas punggung bawah adalah salat. ${ }^{2}$ Salat terdiri dari tujuh posisi disetiap rakaatnya dan posisi ini memiliki kesamaan dengan posisi yoga sehingga salat dapat bermanfaat sebagai latihan peregangan pada otot-otot tubuh bila dilakukan secara rutin. ${ }^{3}$

Gerakan salat terdiri dari takbir, berdiri, rukuk, sujud, dan duduk. Setiap gerakan salat melibatkan beberapa kontraksi dan relaksasi otot. ${ }^{4}$ Gerakan kontraksi dan relaksasi yang dilakukan dengan seimbang dapat meningkatkan fleksibilitas. Gerakan rukuk dan sujud yang dilakukan selama 15 detik dapat meregangkan otot-otot punggung bawah dan paha sehingga meningkatkan fleksibilitas punggung bawah. ${ }^{5}$

Pada kegiatan pengabdian masyarakat ini, dilakukan penilaian fleksibilitas punggung bawah pada pengrajin kain blongsong di Kelurahan Tuan Kentang Kecamatan Seberang Ulu 1 Kota Palembang dan edukasi mengenai manfaat gerakan salat sebagai upaya perawatan fleksibilitas punggung bawah.

\section{TINJAUAN PUSTAKA}

Fleksibilitas adalah kemampuan untuk melakukan gerakan dalam ruang gerak sendi yang ditentukan oleh elastisitas otot-otot, tendon, dan ligament. ${ }^{6}$ Dari definisi di atas, dapat disimpulkan bahwa fleksibilitas merupakan kemampuan sendi untuk bergerak melalui berbagai gerakan tanpa disertai rasa sakit yang ditentukan oleh elastisitas otot dan struktur lainnya. Panjang otot bersama dengan integritas sendi dan ekstensibilitas jaringan ikat menentukan fleksibilitas. Fleksibilitas dikaitkan dengan ekstensibilitas muscle tendon unit (MTU) yang menyelimuti sendi. Ligamen dan otot yang tegang akan membatasi 
ekstensibilitas. Hal ini menjadi inhibitor paling besar untuk ROM sendi. Ketika jaringan tersebut tidak terulur (strecth), ekstensabilitasnya akan menurun. ${ }^{7}$

Banyak faktor yang mempengaruhi fleksibilitas, diantaranya viskoelastisitas otot, ligamen, jaringan ikat, dan mobilitas atau hipomobilitas sendi. Keterbatasan pada strukturstruktur ini dapat disebabkan oleh immobilisasi lama, trauma, gangguan tendo atau fasia, dan sedentary lifestyle. Ketika terjadi penurunan fungsi fleksibilitas, dapat menyebabkan nyeri dan meningkatkan risiko cedera. ${ }^{8}$ Elastisitas otot akan berkurang setelah immobilisasi dalam waktu yang lama. Sebaliknya, peregangan otot yang teratur dapat meningkatkan elastisitas otot. Tujuan dari latihan fleksibilitas adalah untuk meningkatkan elastisitas otot sehingga mencapai keadaan yang maksimal. ${ }^{7}$ Oleh karena itu, dibutuhkan latihan peregangan (stretching exercise) yang rutin untuk mencapai fleksibilitas yang maksimal karena fleksibilitas dapat menurun apabila tidak dilatih.

Salat adalah ibadah yang dilakukan oleh umat Muslim yang mempunyai karakteristik khusus yaitu latihan ringan hingga sedang dengan durasi yang pendek. Penelitian membuktikan bahwa aktivitas dengan intensitas sedang yang dilakukan setiap hari, dapat memberikan manfaat kesehatan untuk waktu yang lama. Salat yang dilakukan lima kali sehari secara teratur akan membantu menjaga tubuh sepanjang waktu tanpa menyebabkan peregangan berlebihan (strain) atau kelelahan pada otot. Gerakan salat dan latihan peregangan (stretching exercise) memiliki kesamaan. Seperti salat, latihan peregangan (stretching exercise) harus dilakukan dengan rileks, santai, benar, dan teratur. Latihan peregangan dilakukan untuk membantu gerakan tubuh menjadi lebih mudah dengan cara melonggarkan otot-otot yang tegang menyebutkan bahwa latihan seperti ini juga dapat dicapai melalui salat. ${ }^{9}$

\section{METODE}

Pada kegiatan ini, dilakukan kegiatan penyuluhan dan observasi mengenai gerakan sholat yang benar sesuai dengan kaidah ergonomi. Selain itu, dilakukan juga pemeriksaan 
muskuloskeletal serta fleksibilitas pada punggung bawah menggunakan sit and reach test pada pengrajin kain tenun di Kota Palembang.

\section{HASIL DAN PEMBAHASAN}

Telah dilakukan kegiatan pengabdian masyarakat mengenai edukasi manfaat gerakan sholat untuk merawat fleksibilita lumbal untuk pencegahan nyeri punggung bawah pada 30 (tiga puluh) orang pengrajin kain blongsong di Kelurahan Tuan Kentang Kecamatan Seberang Ulu 1 Kota Palembang. Karakteristik pengrajin blongsong berdasarkan jenis kelamin terdiri dari 11 orang laki-laki (36,7\%) dan 19 orang perempuan (63,3\%).

Tabel 1. Karakteristik pengrajin kain blongsong berdasarkan usia

\begin{tabular}{ccc}
\hline Usia & Jumlah & $\%$ \\
\hline $15-25$ tahun & 14 & 46,67 \\
$26-35$ tahun & 5 & 16,67 \\
$36-45$ tahun & 8 & 26,67 \\
$>45$ tahun & 3 & 10 \\
\hline
\end{tabular}

Kegiatan ini dilakukan sebanyak tiga kali kunjungan ke tempat pembuatan kain blongsong. Tahapan kegiatan yang pertama adalah pemeriksaan fleksibilitas punggung bawah pengrajin, lalu kemudian pada kunjungan kedua dan ketiga dilakukan pembinaan mengenai gerakan-gerakan sholat yang benar agar mereka terhindar dari gangguan muskuloskletal terutama pada daerah punggung. 


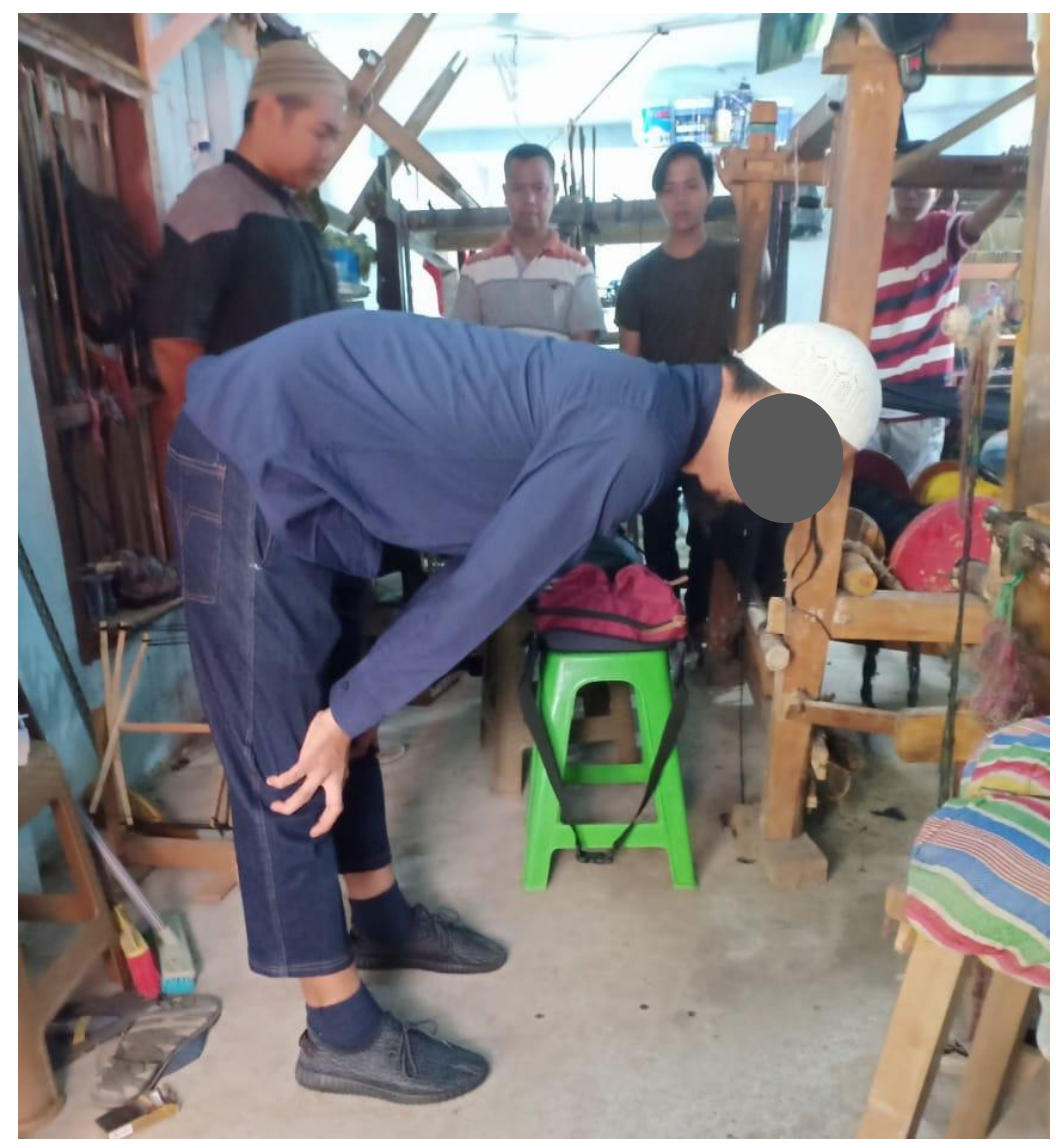

Gambar 1. Demonstrasi gerakan shalat ruku' untuk mencegah nyeri punggung bawah

Penurunan fleksibilitas lumbal kemungkinan merupakan mekanisme kompensasi dari terjadinya kelemahan otot abdomen dan gluteal serta ketegangan otot fleksor panggul akibat postur duduk dalam waktu yang lama. Penelitian mengenai hubungan antara NPB dengan fleksibilitas hamstring yang dilaksanakan di National Hospital of Sri Lanka mendapat hasil bahwa terdapat penurunan pada fleksibilitas hamstring penderita NPB dibandingkan dengan orang sehat. Penurunan pada fleksibilitas hamstring dapat mempengaruhi nilai sit and reach test secara signifikan. ${ }^{10}$

Tabel 2. Pemeriksaan fleksibilitas punggung bawah

\begin{tabular}{lcccc}
\hline \multirow{2}{*}{ No } & \multicolumn{4}{c}{ Nilai fleksibilitas lumbal } \\
\cline { 2 - 5 } & Laki-laki & $\%$ & Perempuan & $\%$ \\
\hline Sangat baik & 4 & 36,4 & 9 & 47.4 \\
Baik & 4 & 36,4 & 3 & 15,8 \\
cukup & 3 & 27,2 & 7 & 36,8 \\
\hline
\end{tabular}




\section{SIMPULAN}

Sebagian besar pengrajin kain blongsong di Kelurahan Tuan kentang memiliki fleksibilitas punggung yang baik. Tidak ada satupun yang memiliki gangguan pada fleksibilitas punggung bawah namun walaupun begitu mereka menyebutkan bahwa memiliki beberapa keluhan pada otot.

\section{Ucapan Terima Kasih}

Ucapan terima kasih ditujukan kepada Dekan Fakultas Kedokteran Universitas Sriwijaya yang telah memfasilitasi pendanaan kegiatan ini melalui dana DIPA Fakultas Kedokteran Universitas Sriwijaya No. SP DIPA-042.01.2.400953/2019, sesuai dengan Surat Perjanjian Nomor: 109/002/UN9.1.4/PLP-PPM/PL/X/2019 Tanggal: 1 Oktober 2019. Ucapan terima kasih juga disampaikan kepada teman-teman sejawat yang telah berpartisipasi dalam kesuksesan kegiatan ini.

\section{Referensi}

1. Putra IGBU, Muliarta IM. Fleksibilitas anak sekolah dasar di kota denpasar usia 9-13 tahun yang bermain wushu lebih baik dari pada bukan pemain wushu. E-jurnal med udayana. 5(10).

2. Yasmita D, Herawati I. Pengaruh pemberian core stability exercise terhadap peningkatan fleksibilitas lumbal pada pasien low back pain miogenik di RSU Mokopido Tolitoli. 2018.

3. Anggraeni RR. Manfaat peregangan otot terhadap keluhan nyeri punggung bawah pada pekerja bagian knitting gantung PT. Royal Korindah Purbalingga. 2015.

4. Hapsari E. Inilah manfaat dan rahasia di balik gerakan shalat. [internet] Available from https://www.republika.co.id/berita/dunia-islam/khazanah/12/08/10/m8j9ks-inilahmanfaat-dan-rahasia-di-balik-gerakan-shalat-1.

5. Nazish N, Karla N. Muslim prayer-a new form of physical activity: a narrative review International Journal of Health Sciences \& Research. 2018;8(7):337-44.

6. Noveila AG. Stretching pada penderita hamstring tightness. Http://repository.unair.ac.id/39910/1/abstrak.pdf.

7. Agustin D. Fleksibilitas otot hamstring pada kasus tightness hamstring program studi s1 fisioterapi fakultas ilmu kesehatan. 2013.

8. Einerman C, Eleff E, Ilijeska A, Zinberg A. CUNY academic works the effects of morning 
versus evening stretching exercises in hamstrings flexibility gains. 2014.

9. Daniati RR. Penatalaksanaan terapi latihan pada kondisi pasca operasi sectio caesarea di RSUD DR. Moewardi Surakarta. 2008. Available from http://eprints.ums.ac.id/2750/2/J100050003.pdf.

10. Hasarangi LBS, Jayawardana DGSK. Comparison of hamstring flexibility between patients with chronic lower back pain and the healthy individuals at the National Hospital of Sri Lanka. 2018;5(2):4410-13. doi:10.26717/BJSTR.2018.05.001171. 